\title{
ANALISIS PENGGUNAAN CAMPUR KODE DALAM VLOG ATTA HALILINTAR : KAJIAN SOSIOLINGUISTIK
}

\author{
Novhira Putri Paino \\ Program Studi Pendidikan Bahasa dan Sastra Indonesia \\ Universitas Negeri Medan \\ Jalan Williem Iskandar Pasar V Medan Estate, Medan \\ surel: novhiraputri099@gmail.com
}

\begin{abstract}
Abstrak
Penelitian ini bertujuan untuk mengetahui bentuk campur kode pada vlog Atta Halilintar berdasarkan kajian Sosiolinguistik. Data atau video yang dianalisis yaitu tiga video dari channel youtubenya Atta Halilintar. Pada kesempatan kali ini penyusun akan membahas tentang Analisis Penggunaan Campur Kode dalam Konten Video Atta Halilintar pada tahun 2020. Data penelitian ini berupa tuturan dari video youtube Atta Halilintar. Penelitian ini menggunakan penelitian kualitatif dengan metode deskriptif yang menghasilkan data deskriptif berupa kata-kata yang bertujuan untuk memahami fenomena sosial termasuk fenomena kebahasaan. Teknik yang digunakan dalam pengumpulan data adalah teknik catat. Data diperoleh secara langsung dengan pencatatan semi struktur yakni mentranskrip ungkapan suara dan video dari handphone kemudian dianalisis untuk mengetahui bagaimana bentuk campur kode tersebut. Pada penelitian ini ditemukan dua jenis campur kode, yaitu jenis campur kode ke dalam, dan jenis campur kode ke luar. Hasil dari penelitian ini, jenis campur kode dominan adalah jenis campur kode ke luar sebanyak 86 data atau 97\%, sedangkan jenis campur kode campur kode ke dalam berjumlah 2 data atau 3\%.
\end{abstract}

Kata Kunci : campur kode, vlog, Atta Halilintar

\begin{abstract}
This research was conducted to determine the form of code mixing in the Atta Halilintar vlog video in sociolinguistic studies. The data or videos that will be discussed are three videos from Atta Halilintar's YouTube channel. On this occasion the compilers will discuss the Analysis of the Use of Mix Codes in the Atta Halilintar Vlog in 2020. The data of this research is in the form of a speech from the Atta Halilintar youtube video. This study uses qualitative research with descriptive methods that produce descriptive data in the form of words that aim to understand social phenomena including linguistic phenomena. The technique used in data collection is the note taking technique. The data were obtained directly by recording semi-structures, namely transcribing voice and video expressions from cellphones, then analyzed to determine how the code was mixed. In this study, two types of code mixing were found, namely the inward mixing type and the outward code mixing type. The results of this study, the dominant code mixing type was the outgoing code mixing type as much as 86 data or $97 \%$, while the inward code mixing type amounted to 2 data or $3 \%$.
\end{abstract}

Keywords: code mix, vlog, Atta Halilintar.

\section{A. PENDAhuluan}

Masa sekarang, sebagian besar masyarakat di Indonesia memiliki kemampuan berbahasa asing. Bahasa menjadi hal terpenting dalam melakukan komunikasi, dalam penyampaian kepada orang lain tentang ide atau gagasan oleh seseorang. Berbahasa tidak pernah tertinggal dalam aktivitas manusia sehari-hari dalam bentuk apapun, karena bahasa 
berperan penting dalam kehidupan manusia.

Masyarakat Indonesia mengenal tiga macam bahasa, yakni bahasa nasional, yaitu bahasa Indonesia, bahasa daerah (bahasa jawa, bahasa sunda dan sebagainya), dan bahasa asing (bahasa negara lain seperti bahasa melayu, bahasa Inggris, bahasa Arab dan sebagainya). Keberagaman bahasa di Indonesia terjadi karena Indonesia terdiri dari berbagai macam suku dan daerah dengan bahasa masing-masing. Hal itu yang menyebabkan adanya kebiasaan menggunakan dua bahasa sekaligus ketika masyarakat Indonesia berkomunikasi, entah bahasa Indonesia disisipkan bahasa daerah ataupun bahasa asing.

Selain memudahkan manusia dengan teknologi yang semakin canggih, perubahan zaman yang kian berkembang memudahkan manusia untuk mengetahui bahasa asing dan dapat pula meniru serta menerapkan dalam komunikasi pada kehidupan seharu-hari, hal itu yang menyebabkan peristiwa campur kode dapat ditemukan dimanapun. Tidak dapat dipungkiri bahwa dalam kehidupan sehari-hari, manusia selalu berinteraksi dengan sesamanya. Situasi kebahasaan adalah faktor sosial dimana bahasa ditempatkan sebagai kode, tingkah laku budaya, lambang dalam masyarakat. Pada umumnya, masyarakat Indonesia adalah masyarakat bilingual atau menggunakan dua bahasa dalam kehidupan sehari-hari, masyarakat Indonesia minimal menguasai dua bahasa yang digunakan dalam interaksi sosial sehari-hari. Hal tersebutlah yang mengakibatkan adanya pengaruh antar bahasa yang menyebabkan adanya kontak bahasa.

Bermula dari masyarakat Indonesia yang menggunakan dua bahasa yaitu bahasa nasional (bahasa Indonesia) dan bahasa daerah, namun seiring berjalannya waktu dan adanya dukungan perkembangan teknologi, masyarakat Indonesia mulai mengenal dan menggunakan bahasa asing, seperti penggunaan bahasa Inggris pada golongan tertentu dikarenakan tuntutan pendidikan ataupun pekerjaan. Masa sekarang, tidak rugi apabila masyarakat Indonesia memiliki kemampuan berbahasa lebih dari dua bahasa (bahasa nasional dan bahasa daerah) yang sering disebut dengan kemampuan multilingual, misalnya penggunaan bahasa Indonesia, bahasa Jawa, dan bahasa Inggris. Era milenial seperti sekarang ini, menguasai bahasa asing seakan-akan adalah tuntutan bagi masyarakat, terutama untuk menguasai bahasa internasioanal yaitu bahasa Inggris. Namun, penggunaan bahasa Indonesia yang baik dan benar tetap harus diperhatikan oleh masyarakat pada situasi dan kondisi tertentu. Misalnya sedang menghadiri acara formal, penggunaan bahasa Indonesia yang baik dan benar tanpa menghilangkan kaidah bahasa Indonesia sangat 
diperlukan. Hal itu diperlukan supaya kosakata dan kaidah berbahasa Indonesia tetap ada dan tidak tergantikan oleh bahasa asing karena seringnya penggunaan kosakata bahasa asing.

Campur kode atau code mixing adalah salah satu kajian konsentrasi dalam sosiolinguistik. Code mixing adalah penggunaan kosakata dari dua atau lebih unsur bahasa oleh satu masyarakat tutur. Fenomena campur kode dapat dilihat langsung dalam bahasa lisan seseorang pada saat berkomunikasi dengan lawan bicaranya, baik di tempat umum, instansi tertentu, dan dimanapun. Fenomena code mixing dapat ditemukan di berbagai media, seperti bahasa tulis pada media cetak ataupun media elektronik. Pada kesempatan kali ini penulis mengamati fenomena campur kode dalam konten video Atta Halilintar. Tujuan pada penelitian ini adalah untuk mendeskripsikan bentuk code mixing pada konten video Atta Halilintar.

\section{B. KAJIAN TEORI}

Bahasa adalah alat komunikasi yang digunakan oleh manusia untuk berinteraksi satu sama lain. Berdasarkan pernyataan Soetjiningsih (2012, hlm.168) bahasa merupakan cakupan sarana komunikasi dengan menyimbolkan gagasan atau isi pikiran dengan perasaan untuk menyampaikan arti atau makna tersirat kepada orang lain. Pada umumnya, di Indonesia penggunaan bahasa oleh masyarakta terdiri dari tiga bahasa, yaitu bahasa nasional atau bahasa Indonesia sebagai bahasa utama, bahasa khas daerah masing-masing, serta bahasa asing. Bahasa yang beragam di Indonesia menjadikan masyarakat dapat menguasai bahasa yang beragam, maka dari itu, masyarakat Indonesia memiliki kemampun bilingual atau dwibahasa bahkan multilingual.

Code mixing bukan hanya ditemukan pada dunia nyata, namun dapat pula ditemukan pada dunia maya seperti media sosial. Media sosial memudahkan manusia untuk berinteraksi dengan siapaun dimanapun dan kapanpun. Code mixing atau campur kode adalah penggunaan dua atau lebih bahasa. Terjadinya campur kode apabila penggunaan suatu bahasa lebih dominan yang disisipi dengan unsur bahasa lain. Biasanya hal ini ada hubungannya dengan karekter dan latar belakang sosial pembicara tersebut. Ciri penggunaan campur kode yang menonjol biasanya pada suasana santai dan nonformal. Namun, hal ini dapat terjadi pula karena adanya keterbatasan dalam ungkapan pada bahasa yang digunakan tidak ada padanannya, sehingga terpaksa harus menggunakan bahasa lain untuk menddukung satu fungsi bahasa. 
Berdasarkan pernyataan Kahcru (Rokhman, 2013, hlm.38), campur kode adalah menggunakan dua atau lebih unsur bahasa dengan cara mencampurkan unsur antar bahasa secara konsisten. Code mixing merupakan satu-kesatuan suatu bahasa ke satu araah (konvergensi kebahasaan). Campur kode dengan interfensi adalah hal yang serupa, interfensi adalah terjadinya penyimpangan dari satu bahasa ke bahasa lainnya. Terjadinya code mixing atau kode campur, pembicara menyisipkan unsur bahasa lain saat menggunakan bahasa tertentu kepada lawan bicara. Unsur bahasa tersebut tidak hanya berupa kata-kata, namun dapat pula berupa frasa atau kelompok kata.

Campur kode terjadi karena adanya latar belakang yang terdiri dari dua golongan, yaitu: latar belakang sikap pembicara dan latar belakang keterbatasan bahasa, sehingga terdapaat alasan identifikasi peranan, identifikasi ragam, dan keinginan untuk menjelasakan. Wujud dari code mixing atau campur kode sebagai berikut, menyisipkan kata, penyisipan frasa, menyisipkan klausa, menyisipkan ungkapan, dan menyisipkan bentuk baster. Tidak berbeda dengan alih kode, masyarkat tutur dengan kemampuan bilingual bahkan multilingual yang menyebabkan terjadinya campur kode. Namun, ada perbedaan antara campur kode dengan alih kode, campur kode memiliki maksud yang jelas tanpa disadari digunakan oleh pembicara, atau bisa juga disebut sebagai reflek pembicara menggunakan pengetahuan bahasa asing yang dimiliki. Berdasarka pernyataan Wijana (2012), campur kode terjadi karena danya dua bagian sebab, yang pertama adalah skap atau attitudianl tipe yaitu latar belakang sikap pembicara, yang kedua adalah kebahasaan atau linguistik tipe yaitu latar belakang keterbatasan bahasa, sehingga ada alasan identifikasi peranan, ragam, dan keinginan untuk menjelaskan atau menafsirkan tuturan. Maka demikian, campur kode dapat terjadi karena adanya hubungan timbal balik antara peranan penutur dan lawan tutur, bentuk dan fungsi bahasa.

Menurut Nababan (dalam Suandi, 2014) tuntutan situasi bukan penyebab terjadinya campur kode, namun karena kebiasaan. Campur kode terjadi karena latar belakang sosial, ciri terjaddinya campur kode biasanya ketika situasi non formal. Dapat disimpulkan bahwa campur kode terjadi bukan karenan tuntutan situasi atau konteks pembicaraan, namun adanya saling ketergantuan antar bahasa yang mengutamakan peran dan fungsi bahasa yang terjadi pada situasi dan kondisi non-formal.

Menurut Redlinger dan Park (dalam Padmadewi dkk, 2014), menyatakan bahwa campur kode dapat terjadi karena adanya alasan tertentu, antara lain: 
1. Anak hanya menguasai dengan baik satu bahasa dan belum menguasai bahasa lain, hal itu mengakibatkan anak melakukan campur kode antara bahasa yang dikuasi dengan bahasa yang belum dikuasai dengan baik.

2. Campur kode terjadi apabila istilah yang dibutuhkan belum ada pada bahasa yang digunakan, sehingga menggunakan istilah dari bahasa lain.

3. Apabila penggunaan kata lebih kompleks dari pada kata pada bahasa lain, anak menggunakan istilah pada bahaa lain yang lebih mudah.

4. Apabila input yang diterima anak menggunakan bahasa campur, maka anak akan menjawab sebagaimana input yang diterima.

Pendapat lain menurut Jendra (dalam Padmadewi, dkk. 2014), campur kode terdiri dari tiga macam yaitu, (1) campur kode ke dalam (inner code mixing) adalah penyerapan unsur bahasa asli yang masih sekeluarga, seperti campur kode bahasa Indoensia terdapat unsur bahasa Jawa didalamnya, (2) campur kode ke luar (outer code mixing) yaitu penyerapan bahasa asing, seperti penggunaan bahasa Indonesia yang dicampur dengan bahasa Inggris, dan (3) campur kode campuran (hybrid code mixing) adalah penyerapan unsur bahasa asli dan asing.

Adapun pendapat Nababan (dalam Suandi, 2014) campur kode digolongkan menjadi dua, yaitu (1) Campur Kode Ke Luar (Outer Code-Mixing), campur kode yang menyampurkan bahasa assli dengan bahasa asing, contoh bahasa Indonesia dicampur dngan bahasa Belanda, (2) Campur Kode Ke Dalam (Inner Code-Mixing), campur kode pencampuran bahasa asli Indonesia dengan variasi bahasa daerah, seperti pencampuaran bahasa Indonesia dan Jawa (dialek lokal).

Komunukasi adalah proses berinteraksi dalam kehidupan manusia, komunukasi dapat dilakukan menggunakan media yang disebut komunukasi massa. Adanya komunikasi massa berdasarkan teknologi, pola penyebaran, dan cara mengakses. Seiring perkembangan zaman, media pun berkembang, hal itulah yang mengakibatkan adanya media lama (old media) dan media baru (new media). Jadi, media lama telah tergeser oleh media yang menggunakan internet yang dapat diakses kapanpun dimanapun dan sumber yang beragam.

Menurut David, dkk (2017) vlog adalah blog dalam bentuk video, vlog adalah video tentang opini, jurnal harian yang biasa dimuat dalam blog. Awalnya, vlog adalah sarana untuk berekspresi dan menyampaikan pendapat kepada publik. Pada akhirnya, vlog berisi tentang ekspresi diri secara bebas sehingga tidak sedikit vlogger yang berbahasa asing pada 
videonya. Banyaknya vlog yang diunggah pada sosial media menjadi hiburan rutin bagi berbagai kalangan. Vlog adalah konten yang dikategorikan pemberi informasi baik secara umum maupun khusus (pribadi), karena banyak vlog yang berisi tentang informasi pribadi seperti vlog tentang: (1) Kegiatan harian; (2) Opini; (3) Curahan hati vlogger.

\section{METODE PENELITIAN}

Metode dalam penelitian ini adalah penelitian deskriptif kualitatif. Metode deskriptif kualitatif adalah metode penelitian yang memperhatikan data, menekankan aspek pemahaman mendalam pada masalah tertentu. Metode kualitatif menghasilkan data tertulis. Penelitian ini bertujuan untuk menganalisis campur kode pada vlog youtuber nomer satu di Asia yaitu Atta Halilintar. Dalam penelitian ini, sumber data yang digunakan adalah tiga video dari channel youtube Atta Halilintar tahun 2020. Peneliti mengambil tiga sampel video untuk dianalisis, antara lain berjudul 1) Atta Jemput Fateh Sekolah Pertama Kali Pake Mobil i8. RUSUH! 2) Atta Aurel Dipaksa Nikah Keluarga, 3).Penghasilan Youtube Atta untuk Mereka Semua! Data yang digunakan dalam penelitian ini adalah tutur kata yang termasuk code mixing dalam vlog Atta Halilintar pada ketiga judul di atas.

\section{HASIL DAN PEMBAHASAN}

Penuturan pada video vlog Atta Halilintar terdapat tuturan campur kode. Bentuk campur kode pada video vlog Atta Halilintar berupa kata, klausa, pengulangan kata (reduplikasi) dan kalimat pada bahasa Inggris, bahasa Indonesia, dan bahasa Minang. Campur kode yang sering ditemukan adalah penyisipan unsur kata dan kalusa dalam bahasa Inggris dengan bahasa Indonesia. Atta Halilintar selaku subjek dalam penelitian merupakan seseorang yang memiliki kemampuan bilingual yang terkenal di kalangan masyarakat Indonesia, khusunya terkenal pada kalangan pemuda, sehingga dapat terjadi peristiwa bentuk campur kode antara berbahasa Indonesia, berbahasa Inggris, maupun bahasa daerah.

Penulis dapat mengumpulkan 88 data pada penelitian ini. Data yang dikumpulkan berupa penggunaan kalimat yang mengandung jenis dan bentuk campur kode yang sesuai dengan penelitian. Dari data yang terkumpul, ditemukan dua jenis campur kode, yakni campur kode ke dalam dan campur kode ke luar.

\section{Campur Kode ke Dalam}


Campur kode ke dalam ialah campur kode yang menyerap unsur bahasa daerah yang massih sekerabat. Pada penelitian ini campur kode ke dalam berupa penurutan menggunakan bahasa Indonesia yang dicampur dengan unsur bahasa Minang. Berikut tabel 1 hasil analisis campur kode ke dalam.

Tabel 1

Campur Kode ke Dalam Bahasa Minang

Judul Video : "Atta Aurel Dipaksa Nikah Keluarga"

\begin{tabular}{crll}
\hline No. Durasi ke- & \multicolumn{2}{c}{ Data } & $\begin{array}{l}\text { Makna Bahasa } \\
\text { Indonesia }\end{array}$ \\
\hline 1. & 3.17 & $\begin{array}{l}\text { "Bapak ambo, ini anak } \\
\text { ambo!." }\end{array}$ & ambo 'saya' \\
\hline 2. & 3.31 & $\begin{array}{l}\text { "Ini bapak ambo bukan orang } \\
\text { Padang." }\end{array}$ & ambo 'saya' \\
\hline
\end{tabular}

Berdasarkan tabel 1, fakta kebahasaan mengenai campur kode ke dalam dalam konten video Atta Halilintar berjumlah dua data. Terdiri dari penggunakan struktur bahasa Indonesia dengan menyerap unsur bahasa Minang berjumlah 1 data, yaitu (1) ambo "saya". Penggunaan kata tersebut menjelaskan bahwa Atta memperkenalkan seseorang yang berperan sebagai bapaknya di film terbarunya. Dan seseorang tersebut juga memperkenalkan bahwa Atta merupakan anak yang pintar dan berbakat.

\section{Campur Kode ke Luar}

Campur kode ke luar adalah macam campur kode yang menggunakan unsur bahasa asing. Pada peneltian ini, campur kode ke luar adalah pemakaian bahasa Indonesia dengan campuran bahasa Inggris. Untuk lebih jelas berikut analisisnya pada tabel 2, 3, dan 4.

Tabel 2

Campur Kode ke Luar Bahasa Inggris

Judul Video : "Atta Jemput Fateh Sekolah Pertama Kali Pake Mobil i8. RUSUH!"

\begin{tabular}{llll}
\hline No. & Durasi ke- & Data & $\begin{array}{l}\text { Makna Bahasa } \\
\text { Indonesia }\end{array}$ \\
\hline 1. & 0.09 & "Subscribe dulu ya guys." & subscribe 'langganan'
\end{tabular}




\begin{tabular}{llll}
\hline 2. & 0.17 & "Dia marah guys." & guys 'kalian' \\
\hline 3. & 0.22 & "Subscribe itu gratis." & subscribe 'langganan' \\
\hline 4. & 0.23 & "untuk upload setiap hari." & upload 'unggah' \\
\hline 5. & 0.31 & "Enjoyyy..." & enjoy 'santai' \\
\hline 6. & 0.55 & "Whatsapp guys." & $\begin{array}{l}\text { whatsapp guys 'apa kabar } \\
\text { kalian(menyapa) }\end{array}$ \\
\hline 7. & 0.57 & "Bye bye." & bye-bye 'selamat tinggal'
\end{tabular}

\begin{tabular}{|c|c|c|c|}
\hline 8. & 0.58 & $\begin{array}{l}\text { "Selamat datang lagi di channel } \\
\text { Atta Halilintar." }\end{array}$ & channel 'saluran' \\
\hline 9. & 1.16 & $\begin{array}{l}\text { "Temen-temen pada nge-request } \\
\text { aku jemput adek." }\end{array}$ & request 'permintaan' \\
\hline 10. & 1.27 & $\begin{array}{l}\text { "Sebagai abang kita harus support } \\
\text { ya guys." }\end{array}$ & $\begin{array}{l}\text { support 'mendukung' dan } \\
\text { guys 'kalian' }\end{array}$ \\
\hline 11. & 2.20 & "Sekolah Islamic dimana sih?" & Islamic 'islam' \\
\hline 12. & 3.10 & "Hello..." & hello 'sapaan' \\
\hline
\end{tabular}

13. $4.31 \quad$ "ngambek guys." guys 'kalian’

\begin{tabular}{|c|c|c|c|}
\hline 14. & 9.36 & $\begin{array}{l}\text { "Gue abis dipalakin sama anak- } \\
\text { anak guys." }\end{array}$ & guys 'kalian' \\
\hline 15. & 9.39 & "Gokil guys, gue jajan guys." & guys 'kalian' \\
\hline 16. & 10.19 & "ni coach-nya nih" & coach 'pelatih' \\
\hline 17. & 10.48 & "Goall!!!"” & goal 'tepat sasaran' \\
\hline 18. & 11.36 & "Thank you semua, makasih." & thank you 'terima kasih' \\
\hline 19. & 11.50 & "Sekarang ibu-ibu guys." & guys 'kalian' \\
\hline 20. & 12.07 & $\begin{array}{l}\text { "Aku harus ready sepatu futsal, } \\
\text { bola futsal guys." }\end{array}$ & $\begin{array}{l}\text { ready 'mulai' dan guys } \\
\text { 'kalian' }\end{array}$ \\
\hline 21. & 12.09 & $\begin{array}{l}\text { "Di kota manapun aku harus } \\
\text { ready." }\end{array}$ & ready 'mulai' \\
\hline 22. & 13.06 & "eh...love ye." & love 'suka' \\
\hline
\end{tabular}




\begin{tabular}{|c|c|c|c|}
\hline 23. & 13.10 & $\begin{array}{l}\text { "Thank you semuanya..makasih } \\
\text { banyak." }\end{array}$ & thank you 'terima kasih' \\
\hline 24. & 13.19 & "Love you guys." & $\begin{array}{l}\text { love you 'cinta kamu' dan } \\
\text { guys 'kalian' }\end{array}$ \\
\hline 25. & 13.24 & $\begin{array}{l}\text { "Aku disuruh pegang kamera } \\
\text { guys." }\end{array}$ & guys 'kalian' \\
\hline 26. & 14.09 & $\begin{array}{l}\text { "Oke guys. Thank you udah } \\
\text { nonton videoku kali ini." }\end{array}$ & $\begin{array}{l}\text { guys 'kalian' dan thank you } \\
\text { 'terima kasih' }\end{array}$ \\
\hline
\end{tabular}

Berdasakan tabel di atas, fakta kebahasaan mengenai campur kode ke luar pada video pertama dengan judul "Atta Jemput Fateh Sekolah Pertama Kali Pake Mobil i8. RUSUH!" berjumlah 26 data, terdiri dari campur kode berbahasa Inggris berupa kata, frasa, dan klausa bahasa Inggris yang terdapat di dalamnya. Penggunaan kata, frasa, dan klausa tersebut menjelaskan bahwa Atta menyempatkan bermain futsal dengan adik dan teman-teman adiknya. Lalu, akhirnya pun bola masuk tepat pada sasaran dan dia senang dan berterimakasih kepada orang-orang sekitar yang mendukungnya. Atta pun berterimakasih kepada penggemar dan orang-orang yang telah mendukung dan menonton videonya ini.

\section{Tabel 3}

\section{Campur Kode ke Luar Bahasa Inggris}

\begin{tabular}{|c|c|c|c|}
\hline \multicolumn{4}{|c|}{ Judul Video : “Atta Aurel Dipaksa Nikah Keluarga” } \\
\hline No. & Durasi ke- & Data & $\begin{array}{l}\text { Makna Bahasa } \\
\text { Indonesia }\end{array}$ \\
\hline 1. & 0.48 & $\begin{array}{l}\text { "Jangan lupa guys, subcribe! } \\
\text { Gak ada ruginya kami klik } \\
\text { tombol subcribe." }\end{array}$ & $\begin{array}{c}\text { guys 'kalian' dan } \\
\text { subscribe 'langganan' }\end{array}$ \\
\hline 2. & 0.54 & "Persiapan film Ashiap Man." & $\begin{array}{l}\text { film 'media komunikasi } \\
\text { berbasis video' dan man } \\
\text { 'lelaki' }\end{array}$ \\
\hline 3. & 1.47 & $\begin{array}{l}\text { "Karena saya tau nanti } \\
\text { syutingnya sangat berat, dengan } \\
\text { kita lihat timeline-nya yang } \\
\text { padat." }\end{array}$ & timeline 'garis waktu' \\
\hline 4. & 3.05 & “Papa saya guys di film.” & $\begin{array}{l}\text { guys 'kalian' dan film } \\
\text { 'media komunikasi berbasis } \\
\text { video' }\end{array}$ \\
\hline 5. & 3.13 & $\begin{array}{l}\text { "Ini anak yang ganteng, } \\
\text { berbakat, smart, dan baik hati." }\end{array}$ & smart 'pintar' \\
\hline
\end{tabular}




\begin{tabular}{|c|c|c|c|}
\hline 6. & 4.30 & "Ini siapa? Princess?." & princess 'tuan putri' \\
\hline 7. & 4.44 & "Jadi ini ada 55 scene guys." & scene 'tempat kejadian' \\
\hline 8. & 5.00 & $\begin{array}{l}\text { "Namanya, ehm } \quad \text { oke } \\
\text { slowmo." }\end{array}$ & slowmo 'gerak lambat' \\
\hline 9. & 5.03 & "Oh my God, belum teh." & oh my God 'Tuhanku' \\
\hline 10. & 6.24 & $\begin{array}{l}\text { "Merah pipinya! itu blush } \\
\text { on." }\end{array}$ & blush on 'pemerah pipi' \\
\hline 11. & 8.10 & $\begin{array}{c}\text { "Guys, aku gak mood } \\
\text { makan." }\end{array}$ & $\begin{array}{l}\text { guys 'kalian' dan mood } \\
\text { 'suasana hati' }\end{array}$ \\
\hline 12. & 9.47 & $\begin{array}{l}\text { "Thank you ya, nanti itu ada } \\
\text { preman juga." }\end{array}$ & thankyou 'terima kasih' \\
\hline
\end{tabular}

Berdasakan tabel di atas, fakta kebahasaan mengenai campur kode ke luar pada video pertama yang berjudul "Atta Aurel Dipaksa Nikah Keluarga” berjumlah 12 data, terdiri dari campur kode berbahasa Inggris berupa kata, frasa, dan klausa bahasa Inggris yang terdapat di dalamnya. Penggunaan kata, frasa, dan klausa tersebut menjelaskan bahwa Atta membicarakan lawan mainnya yaitu Aurel yang disebut sebagai tuan putri dan ia menjelaskan bahwa di filmnya terdapat 55 tempat kejadian. Atta juga berusaha menjahili Aurel sehingga pipi Aurel memerah dan memberi tau bahwa ia tidak selera makan. Lalu, ia mengucapkan terima kasih kepada penontonnya.

Tabel 4

Campur Kode ke Luar Bahasa Inggris

Judul Video : “Penghasilan Youtube Atta untuk Mereka Semua!”

\begin{tabular}{|c|c|c|c|}
\hline No. & Durasi ke- & Data & $\begin{array}{l}\text { Makna Bahasa } \\
\text { Indonesia } \\
\end{array}$ \\
\hline 1. & 0.07 & $\begin{array}{c}\text { "Whatsapp Ateam, apa } \\
\text { kabar guys?." }\end{array}$ & $\begin{array}{cc}\text { guys } & \text { 'kalian' } \\
\text { subscribe 'langganan' }\end{array}$ \\
\hline 2. & 0.12 & $\begin{array}{l}\text { "Hari ini aku, akan di } \\
\text { videocall." }\end{array}$ & $\begin{array}{l}\text { film 'media komunikasi } \\
\text { berbasis video' dan man } \\
\text { 'lelaki' }\end{array}$ \\
\hline 3. & 0.18 & $\begin{array}{l}\text { "Pengen buat campaign- } \\
\text { campaign diluar sana." }\end{array}$ & timeline 'garis waktu' \\
\hline 4. & 0.48 & $\begin{array}{l}\text { "Nah, hari ini aku akan di } \\
\text { videocall." }\end{array}$ & $\begin{array}{l}\text { guys 'kalian' dan film } \\
\text { 'media komunikasi berbasis } \\
\text { video' }\end{array}$ \\
\hline
\end{tabular}




\begin{tabular}{|c|c|c|c|}
\hline 5. & 0.54 & "Aku pengen, videocall nih." & smart 'pintar' \\
\hline 6. & 0.56 & $\begin{array}{l}\text { "Temen-temen youtube ku } \\
\text { juga dapat melihat." }\end{array}$ & princess 'tuan putri' \\
\hline 7. & 1.06 & $\begin{array}{l}\text { "Ayo, ini kita tunggu } \\
\text { videocall pertama. (Acara Hitam } \\
\text { Putih)" }\end{array}$ & scene 'tempat kejadian' \\
\hline 8. & 1.29 & $\begin{array}{l}\text { "(Dedi Combuzer) Artinya lo } \\
\text { nggak bikin vlog-vlog di luar lagi } \\
\text { dong?." }\end{array}$ & slowmo 'gerak lambat' \\
\hline 9. & 1.41 & $\begin{array}{l}\text { "(Dedi Combuzer) Sejak } \\
\text { kapan itu Ta? karena gua lihat } \\
\text { kemarin kok vlog lu masih di } \\
\text { luar?." }\end{array}$ & oh my God 'Tuhanku' \\
\hline 10. & 1.48 & $\begin{array}{l}\text { "Nah, gua kan juga lagi buat } \\
\text { film." }\end{array}$ & blush on 'pemerah pipi' \\
\hline 11. & 1.51 & "Jadi waktu di film itu." & $\begin{array}{l}\text { guys 'kalian' dan mood } \\
\text { 'suasana hati' }\end{array}$ \\
\hline 12. & 1.59 & $\begin{array}{l}\text { "(Dedi Combuzer) karena lo } \\
\text { buat vlog di luar itu." }\end{array}$ & thankyou 'terima kasih' \\
\hline 13. & 2.02 & $\begin{array}{l}\text { "(Dedi Combuzer) Berarti } \\
\text { stop ya itu?." }\end{array}$ & stop 'berhenti' \\
\hline 14. & 2.04 & "Latepost, latepost." & $\begin{array}{c}\text { latepost-latepost } \\
\text { 'terlambat menampilkan' }\end{array}$ \\
\hline 15. & 2.20 & $\begin{array}{l}\text { "(Dedi } \quad \text { Combuzer) } \\
\text { Penghasilan youtube yang mana } \\
\text { nih bro?." }\end{array}$ & youtube 'situs web video' \\
\hline 16. & 2.23 & $\begin{array}{c}\text { "(Dedi Combuzer) } \\
\text { exsence atau yang lain?." }\end{array}$ & exsence 'kehadiran' \\
\hline 17. & 2.27 & $\begin{array}{l}\text { "Yang diberitakan baik dan } \\
\text { bagus kan exsence." }\end{array}$ & exsence 'kehadiran' \\
\hline 18. & 4.37 & $\begin{array}{l}\text { "Jadi aku menyumbangkan } \\
\text { exsenceku untuk berjuang di luar } \\
\text { sana." }\end{array}$ & exsence 'kehadiran' \\
\hline 19. & 4.43 & $\begin{array}{l}\text { "(Fanny) Jadi, di rumah buat } \\
\text { konten youtube apa aja Ta?" }\end{array}$ & youtube 'situs web video' \\
\hline 20. & 4.48 & "Pokoknya quality time." & $\begin{array}{ccc}\text { quality } \\
\text { berkualitas' }\end{array}$ \\
\hline 21. & 5.03 & $\begin{array}{l}\text { "Jadi ini, jadi moment juga } \\
\text { lah." }\end{array}$ & moment 'saat' \\
\hline 22. & 5.04 & $\begin{array}{l}\text { "(Dedi Combuzer) Ok, I } \\
\text { think thats good." }\end{array}$ & $\begin{array}{l}\text { Ok, I think thats good. } \\
\text { 'saya pikir itu bagus' }\end{array}$ \\
\hline 23. & 5.07 & $\begin{array}{l}\text { "(Dedi Combuzer) Anyway } \\
\text { kita tau.." }\end{array}$ & Anyway 'bagaimanapun' \\
\hline
\end{tabular}




\begin{tabular}{|c|c|c|c|}
\hline 24. & 5.14 & $\begin{array}{l}\text { "(Dedi Combuzer) bisa } \\
\text { menginspiration, subscriber lo } \\
\text { banyak, followers lo banyak." }\end{array}$ & $\begin{array}{l}\text { inspiration 'inspirasi', } \\
\text { subscriber 'pelanggan', dan } \\
\text { followers 'pengikut' }\end{array}$ \\
\hline 25. & 5.32 & $\begin{array}{l}\text { "(Dedi Combuzer) Gua } \\
\text { minta lo menginspiration orang- } \\
\text { orang di hitam putih agar di } \\
\text { rumah saja." }\end{array}$ & inspiration 'inspirasi' \\
\hline 26. & 5.46 & $\begin{array}{l}\text { "Kita menjadi super hero } \\
\text { untuk dunia." }\end{array}$ & super hero 'jagoan' \\
\hline 27. & 5.51 & $\begin{array}{l}\text { "Jadilah super hero untuk } \\
\text { kita semua." }\end{array}$ & super hero 'jagoan' \\
\hline 28. & 5.59 & $\begin{array}{l}\text { "(Dedi Combuzer) } \\
\text { healthy, sehat terus." }\end{array}$ & stay healthy 'tetap sehat' \\
\hline 29. & 6.01 & $\begin{array}{cc}\text { "(Dedi } & \text { Combuzer) } \\
\text { thank you." }\end{array}$ & $\begin{array}{l}\text { Bro, thank you '(sapaan) } \\
\text { terima kasih' }\end{array}$ \\
\hline 30. & 6.05 & $\begin{array}{l}\text { "Oke guys, satu video sudah } \\
\text { selesai." }\end{array}$ & guys 'kalian' \\
\hline 31. & 6.42 & $\begin{array}{l}\text { "Kalo live } \\
\text { Najwa." }\end{array}$ & live 'siaran langsung' \\
\hline 32. & 7.07 & $\begin{array}{l}\text { "Untuk super hero kita, untuk } \\
\text { pahlawan kita." }\end{array}$ & super hero 'jagoan' \\
\hline 33. & 7.14 & $\begin{array}{l}\text { "Melawan corona virus di } \\
\text { negara kita tercinta." }\end{array}$ & $\begin{array}{lll}\text { corona virus } & \text { 'virus } \\
\text { korona' } & & \end{array}$ \\
\hline 34. & 7.26 & “Oke guys." & Oke guys 'baiklah kalian' \\
\hline 35. & 7.50 & "Klik link di bawah ini." & link 'tautan' \\
\hline 36. & 8.13 & "Stay dirumah aja." & stay 'tetap' \\
\hline 37. & 8.16 & $\begin{array}{l}\text { "Ini perlu diulang campaign } \\
\text { ini." }\end{array}$ & campaign 'kampanye' \\
\hline 38. & 8.18 & “Stay-stay di rumah aja.” & stay-stay 'tetap' \\
\hline 39. & 8.23 & $\begin{array}{l}\text { "Please-please bantu dunia } \\
\text { ini." }\end{array}$ & $\begin{array}{l}\text { please-please } \\
\text { 'permohonan' }\end{array}$ \\
\hline 40. & 8.46 & $\begin{array}{l}\text { "Jika kita tidak care dengan } \\
\text { apa yang terjadi sekarang." }\end{array}$ & care 'peduli' \\
\hline 41. & 8.50 & $\begin{array}{l}\text { "Ini akan ber-impect sangat } \\
\text { buruk dan fatal." }\end{array}$ & impect 'dampak' \\
\hline 42. & 8.54 & $\begin{array}{l}\text { "Iya aku sebagai salah satu } \\
\text { influencer." }\end{array}$ & influencer 'pengaruh' \\
\hline 43. & 8.58 & $\begin{array}{l}\text { "Aktivis } \\
\text { creativepreaneur." }\end{array}$ & $\begin{array}{c}\text { creativepreaneur } \\
\text { 'seseorang pembisnis' }\end{array}$ \\
\hline
\end{tabular}




\begin{tabular}{cccc}
\hline 44. & 9.01 & $\begin{array}{c}\text { "Dengan campaign yang aku } \\
\text { bikin." }\end{array}$ & campaign 'kampanye' \\
\hline 45. & 9.06 & $\begin{array}{c}\text { "Thank you buat semua pata } \\
\text { subscriber ku." }\end{array}$ & subscriber 'pelanggan' \\
\hline 46. & 9.15 & "Im Atta Halilintar." & Im 'saya' \\
\hline 47. & 9.17 & $\begin{array}{c}\text { "Sampai jumpa di video } \\
\text { selanjutnya, peace!" }\end{array}$ & peace 'damai' \\
\hline 48. & 9.18 & "God Bless you." & $\begin{array}{c}\text { God Bless you 'Tuhan } \\
\text { memberkatimu' }\end{array}$ \\
\hline
\end{tabular}

Berdasakan tabel di atas, fakta kebahasaan mengenai campur kode ke luar pada video pertama berjudul "Penghasilan Youtube Atta untuk Mereka Semua!" berjumlah 48 data, terdiri dari campur kode berbahasa Inggris berupa kata, frasa, dan klausa bahasa Inggris yang terdapat di dalamnya. Dalam video ini, penggunaan kata, frasa, dan klausa tersebut menjelaskan bahwa Atta yang bekerja sebagai seseorang yang kreatif dan pembisnis, ia membuat kampanye ataupun bantuan nyata terhadap situasi covid-19. Akhir kata, Atta juga berterima kasih kepada penontonnya dan menyampaikan agar tetap menonton video-video selanjutnya. Dan ia menyampaikan agar tetap damai dan semuanya dalam lindungan Tuhan.

Berdasarkan pembahasan, campur kode yang paling banyak ditemukan dalam konten video milik Atta Halilintar yang berjudul "Penghasilan Youtube Atta untuk Mereka Semua!" adalah campur kode ke luar yaitu campur kode bahasa Indonesia dengan bahasa Inggris. Dalam video tersebut, campur kode keluar terjadi karena adanya faktor keterbatasan bahasa. Faktor keterbatasan bahasa terjadi karena pembicara memiliki perbendaharaan kosakata bahasa Indonesia yang terbatas, sehingga penutur yaitu Atta Halilintar lebih dominan menggunakan istilah dalam bahasa Inggris untuk menggantikan kosakata dalam bahasa Indonesia.

Campur kode dalam video Atta Halilintar memiliki fungsi antara lain: (1) menunjukkan intelektual; (2) hormat pada lawan bicara; (3) penegasan suatu pendapat; (4) pembangkitan selera humor. Dalam video Atta Halilintar terdapat penggunaan bahasa Inggris pada tuturannya untuk menunjukkan kemampuan dalam berbahasa. Selain hal tersebut, adapula tuturan dengan dukungan ilustrasi dan ekspresi lucu sehingga mampu membangkitkan humor penonton. Campur kode pada video Atta Halilintar berfungsi dalam penegasan pendapat. Berikut ini merupakan contoh tuturan dengan fungsi penegasan pendapat: 
8.46 : "Jika kita tidak care dengan apa yang terjadi sekarang."

8.50 : "Ini akan ber-impect sangat buruk dan fatal."

Dalam tuturan Atta Halilintar bercampur kode pada kata care dan impect. Kata care dan impect tersebut diucapkan dengan lantang untuk mengarahkan seluruh masyarakat agar peduli dengan kesehatannya dan juga mengikuti arahan ataupun aturan dari pihak terkait.

\section{E. KESIMPULAN}

Dari hasil penelitian terhadap tiga video milik Atta Halilintar tersebut, antara lain judul dari ketiga video itu 1) Atta Jemput Fateh Sekolah Pertama Kali Pake Mobil i8. RUSUH! 2) Atta Aurel Dipaksa Nikah Keluarga, 3) Penghasilan Youtube Atta untuk Mereka Semua!. Terdapat tururan bercampur kode. Adapun bentuk campur kode yang ditemukan berupa kata, frasa, klausa, pengulangan kata (reduplikasi) dan kalimat dalam bahasa Inggris, bahasa Indonesia dan bahasa Minang. Bentuk campur kode penyisipan unsur kata dan klausa yang ditemukan lebih dominan berbahasa Inggris dan bahasa Indonesia dibandingkan bahasa Minang.

Bedasarkan hasil pembahasan, jenis campur kode pada penelitian ini dominan adalah jenis campur kode ke luar terdiri dari sebanyak 86 data atau 97\%, sedangkan banyaknya jenis campur kode ke dalam sebanyak 2 data atau 3\%. Fenomena yang paling banyak ditemukan yaitu dalam konten video milik Atta Halilintar yang berjudul "Penghasilan Youtube Atta untuk Mereka Semua!" dalam campur kode keluar, yakni campur kode bahasa Inggris.

\section{F. SARAN}

Penulis berharap agar penelitian ini selain dapat dijadikan informasi tambahan untuk memperbaiki penggunaan bahasa, juga dapat menjadi referensi bagi penulis lain, yang ingin mengkaji fenomena kebahasaan sosiolinguistik khususnya penelitian tentang campur kode. Dan semoga penelitian ini dapat bermanfaat bagi pembaca kelak.

\section{DAFTAR PUSTAKA}

A. Laiman, dkk., 2018, “Campur Kode dan Alih Kode Dalam Percakapan di Lingkup Perpustakaan”, Jurnal: Universitas Bengkulu,

(1),https://ejournal.unib.ac.id/index.php/korpus/article/download/5556/2729 
ER. David, dkk., 2017, "Pengaruh Konten Vlog dalam Youtube terhadap Pembentukan Sikap Mahasiswa Ilmu Komunikasi Fakultas Ilmu Sosial dan Politik Universitas Sam Ratulangi”, Jurnal: Acta Diurna, volume https://ejournal.unsrat.ac.id/index.php/actadiurnakomunikasi/article/view/15479

I, Johanes., 2019, "Bentuk, Jenis, dan Faktor Penyebab Campur Kode Iklan Komersial Produk Makanan dan Minuman Pada Stasiun Televisi MNCTV Periode Januari-Maret 2018”, Skripsi: Program Studi Bahasa dan Sastra Indonesia Fakultas Keguruan dan Ilmu Pendidikan Universitas Sanata Dharma, Yogyakarta.

N, Sa'ida., 2018, "Bahasa Adalah Salah Satu Sistem Kognitif Anak". Jurnal: Universitas Muhammadiyah Surabaya, http://journal.umsurabaya.ac.id/index.php/Pedagogi/article/download/1937/1494

R. Hapsari, 2018, "Campur Kode dan Alih Kode dalam Video Youtube Bayu Skak", Jurnal: BAPALA, 5 (2), https://jurnalmahasiswa.unesa.ac.id/index.php/bapala/article/view/24680

Rini, Mira Ayu Setya., 2016, "Alih Kode dan Campur Kode dalam Ceramah Agama K.H. Anwar Zahid”, Skripsi tidak diterbitkan, Surabaya: Unesa.

Rokhman, Fathur., 2013, Sosiolinguistik Suatu Pendekatan Pembelajaran Bahasa dalam Masyarakat Multikultural, Yogyakarta: Graha Ilmu.

Suandi, I. N., 2014, Sosiolinguistik. Yogyakarta: Graha Ilmu.

Soetjiningsih, 2012, Perkembangan Anak dan Permasalahannya dalam Buku Ajar I Ilmu Perkembangan Anak Dan Remaja, Jakarta :Sagungseto .

Padmadewi, Ni Nyoman, dkk., 2014, Sosiolinguistik. Yogyakarta: Graha Ilmu.

Wijana, I Dewa Putu, dan M. Rohmadi., 2012, Sosiolinguistik. Yogyakarta: Pustaka Pelajar. 